\title{
Coastal flood risk within a peri-urban area: Sussex Inlet district, SE Australia
}

\author{
E. F. Asbridge ${ }^{1}$ (D) - D. Low Choy ${ }^{2}$ B. Mackey ${ }^{3} \cdot$ S. Serrao-Neumann ${ }^{2,4} \cdot$ P. Taygfeld ${ }^{2}$. \\ K. Rogers ${ }^{1}$
}

Received: 16 July 2019 / Accepted: 9 June 2021 / Published online: 5 July 2021

(c) The Author(s), under exclusive licence to Springer Nature B.V. 2021, corrected publication 2021

\begin{abstract}
The peri-urban interface (PUI) exhibits characteristic qualities of both urban and rural regions, and this complexity has meant that risk assessments and long-term planning for PUI are lagging, despite these areas representing new developing settlement frontiers. This study aims to address this knowledge gap by modifying an existing approach to quantify and assess flood risk. The risk triangle framework was used to map exposure, vulnerability and biophysical variables; however, in a novel application, the risk triangle framework was adapted by presuming that there is a variation in the degree of exposure, vulnerability and biophysical variables. Within Australia and globally, PUIs are often coastal, and flood risk associated with rainfall and coastal inundation poses considerable risk to communities in the PUI; these risks will be further exacerbated should projections of increasing frequency of extreme rainfall events and accelerating sea-level rise eventuate. An indicatorbased approach using the risk triangle framework that maps flood hazard, exposure and vulnerability was used to integrate the biophysical and socio-economic flooding risk for communities in PUI of the St Georges Basin and Sussex Inlet catchments of south-eastern Australia. Integrating the flood risk triangle with future scenarios of demographic and climate change, and considering factors that contribute to PUI flood risk, facilitated the identification of planning strategies that would reduce the future rate of increase in flood risk. These planning strategies are useful for natural resource managers and land use planners across Australia and globally, who are tasked with balancing socio-economic prosperity for a changing population, whilst maintaining and enhancing ecosystem services and values. The indicator-based approach used in this study provides a cost-effective first-pass risk assessment and is a valuable tool for decision makers planning for flood risk across PUIs in NSW and globally.
\end{abstract}

E. F. Asbridge

emmaa@uow.edu.au

1 School of Earth, Atmospheric and Life Sciences, University of Wollongong, Wollongong, NSW 2522, Australia

2 Cities Research Institute, Griffith University, Nathan, Brisbane, QLD 4111, Australia

3 Griffith Climate Change Response Program, Griffith University, Gold Coast, Qld, Australia

4 Faculty of Arts and Social Sciences, The University of Waikato, Hamilton, New Zealand 
Keywords Coastal $\cdot$ Flooding $\cdot$ Hazard $\cdot$ Exposure $\cdot$ Vulnerability $\cdot$ Risk triangle

\section{Introduction}

The peri-urban interface (PUI) is broadly defined as the transitional area between urban and rural areas. There is a considerable debate regarding the definition of the PUI (Allen 2003; Simon 2008). Some define PUI as the land experiencing growth immediately adjacent to an urban centre (Burnley and Murphy 1995). Others consider PUI to extend to the maximum commuting distance from the rural countryside to the urban area (Nelson and Dueker 1990). Historically it has been perceived that the land use patterns and human behaviours within urban and rural areas were characteristically different and that boundaries could be established on the basis of the differing character between these areas (Simon 2008). However, as urban expansion is rarely uniform, differentiation between rural and urban areas is difficult. Accordingly, issues regarding definition, what are the characteristic qualities of a peri-urban area and how they can be defined spatially, have hampered efforts to establish long-term planning and management of the land and resources base of the PUI (Allen 2003; Buxton and Low Choy 2007; Simon 2008). Historic presumptions regarding the capacity to distinguish urban and rural areas have meant that planning has struggled to manage the dynamics of the transitional interface between rural and urban areas (Simon 2008). This study addresses the knowledge and management gap for PUIs through a spatial approach to managing hazard, exposure, vulnerability and risk. The approach can be applied across regional and global settings and can be modified for the type of risk (i.e. flood, drought or bushfire). The spatial tool and associated data have the capacity to improve and guide natural resource management and land use planning.

This study highlights the need for considerable redress to improve long-term planning for the PUI to accommodate both rural priorities and the increasing needs of expanding urban areas. Allen (2003) proposed that the dichotomy in the planning system for urban and rural areas is deeply ingrained and will fail to meet the planning needs of PUI unless an approach that responds to specific environmental, social, economic and institutional aspects is taken. This study directly addresses this knowledge gap using biophysical, exposure (land use) and vulnerability (socio-economic) data to provide significant advances for PUI land use planning and coastal management policies. Climate change and hazard risk reduction add further urgency to the need for adequate planning in the peri-urban region that responds to the specific environmental, social, economic and institutional needs of PUI. Environmental, climate change and hazard risk assessments tend to focus on areas of high natural resource value or high socio-economic value and neglect the PUI, with the outcome being significant environmental degradation and hazard exposure (Douglas 2012). Yet, as urban areas swell in areal extent to accommodate population growth, periurban areas represent areas of future hazard risk. This study is significant for land use planners and coastal managers, across spatial scales (local, regional and global) as the approach highlights that planning for hazards and risks in peri-urban areas, the new frontiers of urban hazards, is imperative for not only reducing risk to peri-urban populations, but also minimising risks to potential future population centres (Allen 2003).

In Australia, 85\% of the population live within $50 \mathrm{~km}$ of the coast (Trewin 2004), which includes considerable PUIs and commuter zones connected to major cities. 'Sea-change' lifestyle-driven population growth in coastal peri-urban areas (Burnley and Murphy 2004) is a key driver of demographic changes in Australia and a critical issue when planning 
for peri-urbanisation. Sea-change, and the landward tree-change equivalent, has been likened to 'amenity migration', a term used internationally to describe the demographic phenomenon arising from people locating closer to natural amenity and lifestyle opportunities (Gosnell and Abrams 2011; Gurran and Blakely 2007). Whilst this phenomenon can bring jobs to service the increasing population, the new 'migrants' or 'changers' are often of retirement age, or depending upon proximity to major urban centres, may commute elsewhere for work; this establishes a unique set of demographic conditions for PUI planning. The increase in the number of PUIs is not exclusive to Australia, with many first world countries experiencing demographic change as people migrate out of cities for an improved work-life balance. In addition, the recent COVID-19 pandemic appears to have led to a further increase in the demand and net migration to PUIs, according to COVID-19 impact assessments conducted by local government forecasters in NSW (Wollondilly Shire Council 2021). However, long-term patterns of migration are uncertain due to the scale and duration of the pandemic (Bernard et al. 2020). This further highlights the importance of this study and the need to improve land use planning and risk assessments in the face of a changing climate and periods of uncertainty for migration and socio-economic status.

Climate change adds an additional risk dimension to peri-urban populations, altering an area's risk profile in various ways. For example, as the atmosphere warms, projections indicate an increasing potential for extreme rainfall events and flooding risk in many areas of Australia, with national projections indicating a tendency for an increase in the intensity and/or proportion of extreme rainfall (Whetton et al. 2015). Projections indicate that sea-level rise around Australia is comparable to, or even slightly higher than global mean sea-level projections for the suite of Representative Concentration Pathways (RCP) (Whetton et al. 2015), which will further exacerbate flood risk in coastal PUIs, by increasing the vertical position that flood risk may occur and should be accommodated when planning for risk in PUIs.

Fine-resolution modelling approaches, including model utilising-mathematical equations to simulate coastal processes, can be used to characterise the risk of coastal PUIs to flooding of sea-level rise at scales needed for local government assessment and planning (see for example Hartnett and Nash 2017; Wang et al. 2018). However, these approaches are computationally resource intensive and require considerable input data that are not likely to be available for PUIs that have historically received minimal attention. Furthermore, this kind of fine resolution modelling tends to focus on biophysical aspects of flood risk and sea-level rise risk, but rarely integrate models with socio-economic aspects, which are critical for defining the character and risk of PUIs. Whilst the use of sophisticated simulation modelling approaches can be warranted and useful, a practical and readily applicable method is based on developing indicators or indexes using raster (pixel)-based GIS spatial modelling. This approach has been shown to be a cost-effective means of integrating and mapping qualitative and quantitative factors that influence risk (Kaźmierczak and Cavan 2011; Nguyen et al. 2016). These approaches have been widely applied for considering coastal vulnerability to sea-level rise and have been integrated with socio-economic and demographic data to provide a more holistic indication of risk and vulnerability (Nguyen et al. 2016). They can also be used to provide a first-pass risk assessment highlighting locations where more data-intensive and expensive models can be more fruitfully deployed.

Indicator-based approaches using the risk triangle framework have been widely used to map flood risk (Crichton 1999; Granger 2003; Kaźmierczak and Cavan 2011). According to this framework, the flood hazard is a spatial representation of the areas liable to flood, i.e. its geographical extent. Flood hazard can be mapped using biophysical data layers that are based on Earth Observation (EO) datasets of terrain elevation, land 
cover and hydrological dynamics. Flood vulnerability defines which sectors of the community lack the resources needed to prevent, cope and recover from a major flood event. Exposure refers to the land use zones susceptible to flood damage; this often focuses upon urban density and the importance of infrastructure in relation to responding and recovering from a flood event, i.e. residential, commercial and industrial buildings, transport links, access to essential facilities, healthcare facilities, schools, universities and critical services such as police stations and fire stations. Essentially the risk triangle assumes that the risk can be reduced when the length of the sides is shortened. To apply this framework, spatial datasets that characterise flood hazard, vulnerability and exposure are typically mapped and combined to provide a spatially explicit indication of land and communities in PUI at high risk. See Fig. 1.

In this study, flood risk associated with a PUI in south-eastern Australia is examined and an indicator-based approach has been modified and investigated for its effectiveness as a means for a first-pass assessment of flood and sea-level rise risk when planning for PUIs. This study innovatively adapts an existing framework to consider sealevel rise and changing population demographics by weighting significant factors. This novel approach provides the opportunity to further develop a consistent approach to mapping flood hazard, vulnerability and exposure which can be applied across regional and global scales and modified (i.e. swap spatial datasets) for other phenomena (i.e. drought or bushfire). Understanding the contemporary and future dynamics of flood risk and population change requires in-depth analysis of historical land use changes, legacy impacts and future trajectories of change. This study generates land cover archives which are crucial for monitoring and developing relationships between observed changes and coastal processes and pressures. Moreover, in recent years, there have been significant advances in Earth observation technologies, including the addition of new sensors, improvements to the resolution of existing sensors and advanced data archiving capabilities. For example, improvements in Light Imaging and Radar (LiDAR) are providing highly accurate digital elevation models (DEMs) which provide an insight into the biophysical characteristics of the landscape. With the advent of these new datasets and capability, there is a considerable opportunity to improve the accuracy and precision of mapping of coastal hazard and risk. Given the extent and scale of coastal PUIs in Australia, this study provides the most cost-effective means of developing risk assessments and is the only feasible way of quantifying changes at local, regional and national scales and across remote locations.

Fig. 1 Risk triangle, as described by Crichton (1999)

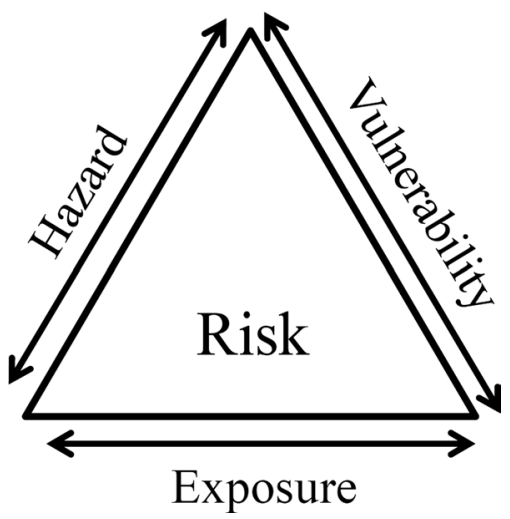


We focus on the Sussex Inlet district, located on the south coast of NSW. This is an ideal locality for considering the multi-faceted aspects of flood risk as the district is largely peri-urban in character and includes a range of natural assets (e.g. beaches, lakes, and forests) that attract populations to the region, and a range of socio-demographic characteristics (e.g. an ageing population, transient residents, increased population in summer and holiday periods, unemployment and lack of residents and visitors in winter months) that when combined influence the flood risk of the land and communities of the PUI. As parts of the study area are low-lying coastal land, flooding is of particular concern in the region, and major flood events are known to have occurred in February 1971, June 1991 and August 2015. Should sea levels rise as projected, it is probable that the frequency of major flood events will increase as the base level increases. It is important to note that whilst this study focuses on the flood risk, Sussex Inlet experiences significant cumulative risk from flood and coastal inundation, drought and fires. The successive events (December 2019/ January 2020: drought and fire, July 2020: flood and March 2021: flood) often compound the recovery of the landscape and local economy and pose a continual threat to life and property.

The aim of this study was to establish the biophysical and socio-economic flooding risk for communities in peri-urban areas of the St Georges Bain and Sussex Inlet catchments and use this as an indication for future flooding risk in the context of a changing climate and socio-economic context. This aim was achieved by:

- Quantifying the changes in land cover within the St Georges Basin and Sussex Inlet district at 10-year intervals (1987, 1997, 2007 and 2017) using a time-series of Landsat imagery to provide an indication of the landscape patterns of peri-urbanisation in the region;

- Compiling a flood hazard map using biophysical layers (slope, elevation, land depression and land cover); flood vulnerability map using socio-economic data (2016 census data) and a flood exposure map using the Landsat land cover mapping and land cover data from the Spatial Services Digital Topographic Database;

- Creating a flood risk map that integrates flood hazard, vulnerability and exposure maps to provide an indication of flood risk associated with peri-urbanisation; and,

- Interpreting flood maps to distinguish factors contributing to peri-urban flood risk.

The results can be used to inform planning strategies that aim to reduce future flood risk associated with climate change and the PUI. This study aimed to provide decision-making guidance for urban and coastal planners and managers to assist with optimising the increasing urban demand in the PUI whilst minimising flood risk.

\section{Methods}

\subsection{Study area}

Sussex Inlet lies primarily within the catchment of St Georges Basin and is located on the southern shore of the narrow entrance that connects St Georges Basin with the ocean. Other villages that occur within the catchment of St Georges Basin include Wandandian, Bewong, Basin View, St Georges Basin (town), Sanctuary Point and Old Erowal Bay. These townships are located on the northern and western sides of St Georges Basin. The 
townships of Cudmirrah and Berrara are regarded to be part of the Sussex Inlet District and are located near the entrances of Swan Lake and Berrara Creek, respectively. As the periurban area of Sussex Inlet and District is associated with three estuaries, St Georges Basin, Swan Lake and Berrara Creek, and biophysical processes associated with flooding are best defined on the basis of drainage basins, the boundaries for the flood risk assessment study area have been defined on the basis of the catchment of the three estuaries associated with Sussex Inlet and District (see Fig. 2).

St Georges Basin, the largest estuary within the study area, is defined as an immature barrier estuary as the degree sediment infill of the bedrock valley over the past 7000 years has been low and the water body is extensive (Roy et al. 2001). St Georges Basin has a surface area of $\sim 40 \mathrm{~km}^{2}$ and drains a $390 \mathrm{~km}^{2}$ catchment (Roy et al. 2001). Tributary creeks into the basin include Cow, Tullarwalla, Pats, Home, Wandandian, Stony, Erowal and Tomerong. The township of Sussex Inlet is primarily located on flood-tide delta sands located behind coastal barrier sands that have accumulated at the entrance to St Georges Basin over the past approximately 7000 years (Troedson et al. 2015). As such, much of the township is very low-lying and is at risk from coastal inundation. As the entrance to St Georges Basin is always open, the township of Sussex Inlet is exposed to flood risk associated with both marine and terrestrial drivers. Consequently, coastal inundation in the region may be a function of rainfall, sea-level rise, storm activity and wave set up in the basin. Other townships located within the catchment of St Georges Basin are variably

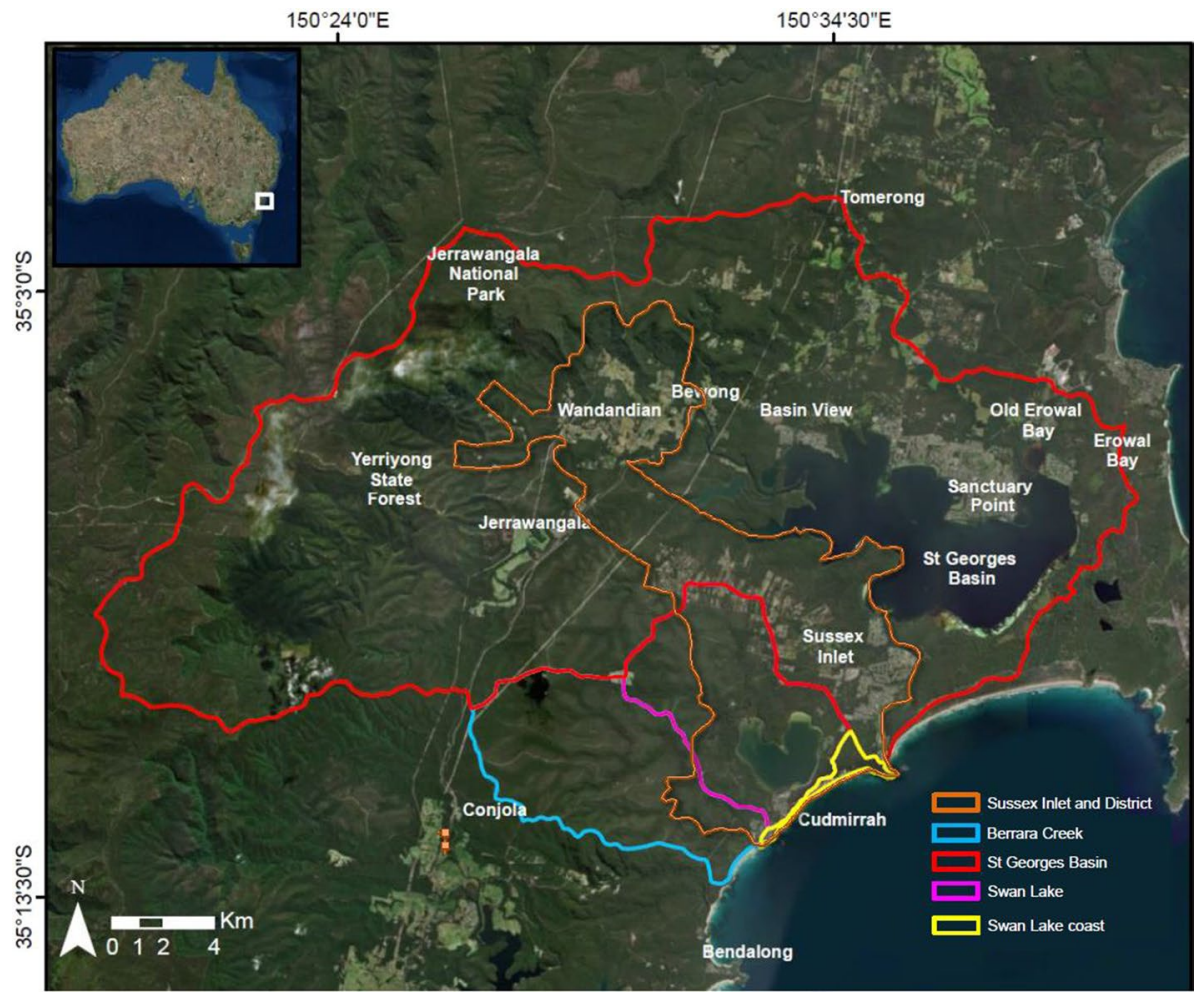

Fig. 2 Study site encompassing the Sussex Inlet and District and associated catchments 
located on a range of lithology including bedrock and low-lying fluvial delta sediments (Troedson et al. 2015).

Swan Lake and Berrara Creek are both smaller in surface area $\left(\sim 4 \mathrm{~km}^{2}\right.$ and $\sim 0.15 \mathrm{~km}^{2}$, respectively) and catchment size $\left(\sim 32 \mathrm{~km}^{2}\right.$ and $\left.\sim 36 \mathrm{~km}^{2}\right)$ than St Georges Basin and have been classified as saline coastal lagoons (Roy et al. 2001). Unlike their larger neighbour, the entrances of both Swan Lake and Berrara Creek intermittently close. Intermittent estuaries, known in Australia as Intermittently Closed and Open Lakes and Lagoons or ICOLLs, exhibit unique management issues (McSweeney et al. 2017; Saintilan et al. 2016). Accordingly, manual entrance opening may be undertaken either to reduce coastal flooding when water levels within the lakes are high or to improve water quality when water levels are low by reinstating tidal exchange.

Whilst the majority of the study area comprising the three catchments is forested ( $80 \%)$, with the remaining areas comprised of grazing and urban land use, the land use has changed significantly since 1970 from a primarily agricultural region to a community experiencing urbanisation and tourism. The region has a number of residential and commercial properties built on low elevation land and as such flooding is a significant risk factor. An important development was the canal estates in 1971 within the Sussex Inlet Township.

Sussex Inlet exhibits characteristics consistent with an increasing 'sea-change' population and is more socially disadvantaged than the national average according to the SocioEconomic Indexes for Areas (SEIFA) index developed by the Australian Bureau of Statistics (ABS). This is likely due to the higher than average proportion of retirees, unemployed and people with low levels of income (as determined from ABS 2016). The 2016 census data identify an ageing population with $42.6 \%>60$ years of age. Other towns in the Shoalhaven region have an average of $31.9 \%$, whilst Sydney has $15.7 \%$. Moreover, $20.6 \%$ of the population lives at or below the poverty line, with $6.9 \%$ unemployed. The number of family households (i.e. medium density housing including semi-detached, townhouses and terraced houses) and apartments is significantly lower in Sussex Inlet compared to Shoalhaven and high proportion (36.7\%) of houses are unoccupied, reflecting the large number of holiday homes.

\subsection{Land cover mapping}

To determine the spatial and temporal land cover distribution, four cloud-free Landsat scenes georeferenced to UTM Zone 56 were acquired from the United States Geological Survey for 1987, 1997, 2007 and 2017. The scenes were converted to GDA94, Zone 56 and processed to surface reflectance by the Queensland Department of Science, Information Technology and Innovation. The extent and distribution of each land cover category was extracted by applying a supervised maximum likelihood classification algorithm. The land cover was split into four broad categories: water bodies, urban, cultivated (i.e. farmland) and uncultivated (i.e. wild remnant land). The classification was validated through reference to aerial photography, NSW Globe digital photography and land use mapping available through Spatial Data Services NSW Government. From the classification the area of each land cover was extracted to identify change over time. As the land cover distribution maps were derived from Landsat scenes, they have a pixel resolution of approximately $30 \mathrm{~m}$. To determine temporal patterns of change in land cover, an image subtraction was undertaken by applying the Raster Calculator in ArcGIS to the land cover maps generated for 1987 and 2017. 


\subsection{Flood hazard mapping}

Four spatial data layers were used to indicate flood hazard (described as Hazard indicators in Table 1): elevation, slope, land depressions and land cover data (derived from the Landsat land cover mapping). Elevation, slope and land depressions were derived from a LiDAR survey collected in 2010 and 2011 and provided by NSW Land and Property Management Authority. The rationale behind each data layer is indicated in Table 1. Elevation provides an insight into exposure, with regions of lower elevation indicating enhanced exposure to storm surges, wave activity, flooding, rainfall and runoff and erosion. The slope was derived within the ArcGIS Spatial Analyst feature. A steep slope will have increased runoff; however, the wave/storm surge will be lessened due to a reduced wave run up. Land depressions indicate localised sinks in the sediment where water may accumulate and flood. The depressions are generated using the fill DEM and subtracting the DEM. The land cover is considered in order to delimit impervious surfaces, i.e. urban land, where enhanced runoff and flooding are likely, as opposed to undisturbed densely vegetated areas (uncultivated) with slower run off velocity and greater substrate permeability.

Each hazard indicator layer was categorised into groups on the basis of cell characteristics that related to the degree of flood hazard (described in Table 1 as cell description) and assigned a flood hazard score, with 1 indicating a low flood hazard and 3 (4 for the elevation layer) indicating a high flood hazard (described in Table 1 as cell score). The areas defined as water bodies, as derived from the land cover classification, were not included in the hazard map as the areas are permanently wet, and not perceived to have any additional hazard associated with flooding.

A final flood hazard map was derived by adding each hazard indicator together using the raster calculator tool in the spatial analyst extension of ArcGIS. As the land cover data have the lowest resolution, this layer was used as the base layer to combine with the other biophysical layers. Accordingly, the ensuing flood hazard map had a pixel resolution of $30 \mathrm{~m}$, with pixel cells ranging between 12 and 3 .

\subsection{Flood vulnerability}

Flood vulnerability was determined based on socio-economic data derived from 2016 census data (ABS 2016). Vulnerability studies have previously used a wide range of indicators to represent community resilience inducing economic, community and infrastructural factors (Bruneau et al. 2003; Norris et al. 2008; Cutter et al. 2010). Based on these studies and available data, we have chosen indicators that align with the consensus within the research community to provide a comparative approach to measure vulnerability. Data collated at the state suburb scale from statistical area 1 (SA1) data were used for mapping flood vulnerability. Suburbs were assigned a vulnerability score for each of the indicators used: age, relationship status, number of residents in a dwelling, education level, language, children (i.e. lone parents, dependents and non-dependents) and employment status. The description of vulnerability indicators, cell scores and cell descriptions are provided in Table 2.

Following the approach for flood hazard mapping, a flood vulnerability map was derived by adding all flood vulnerability indicator layers using the raster calculator tool. A final flood vulnerability map was derived with cell scores ranging between 33, indicating high flood vulnerability, and 11, indicating low flood vulnerability. 


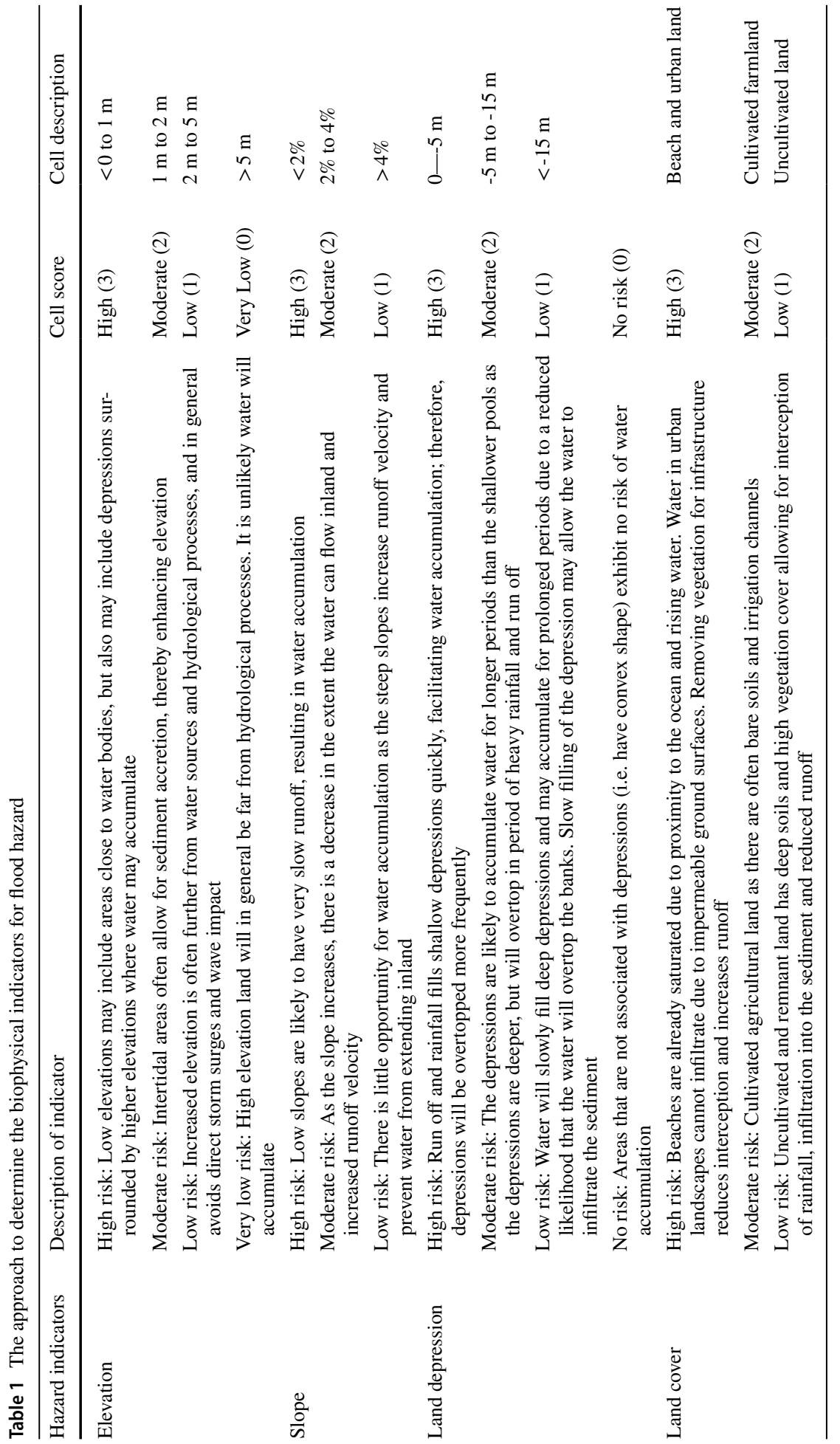



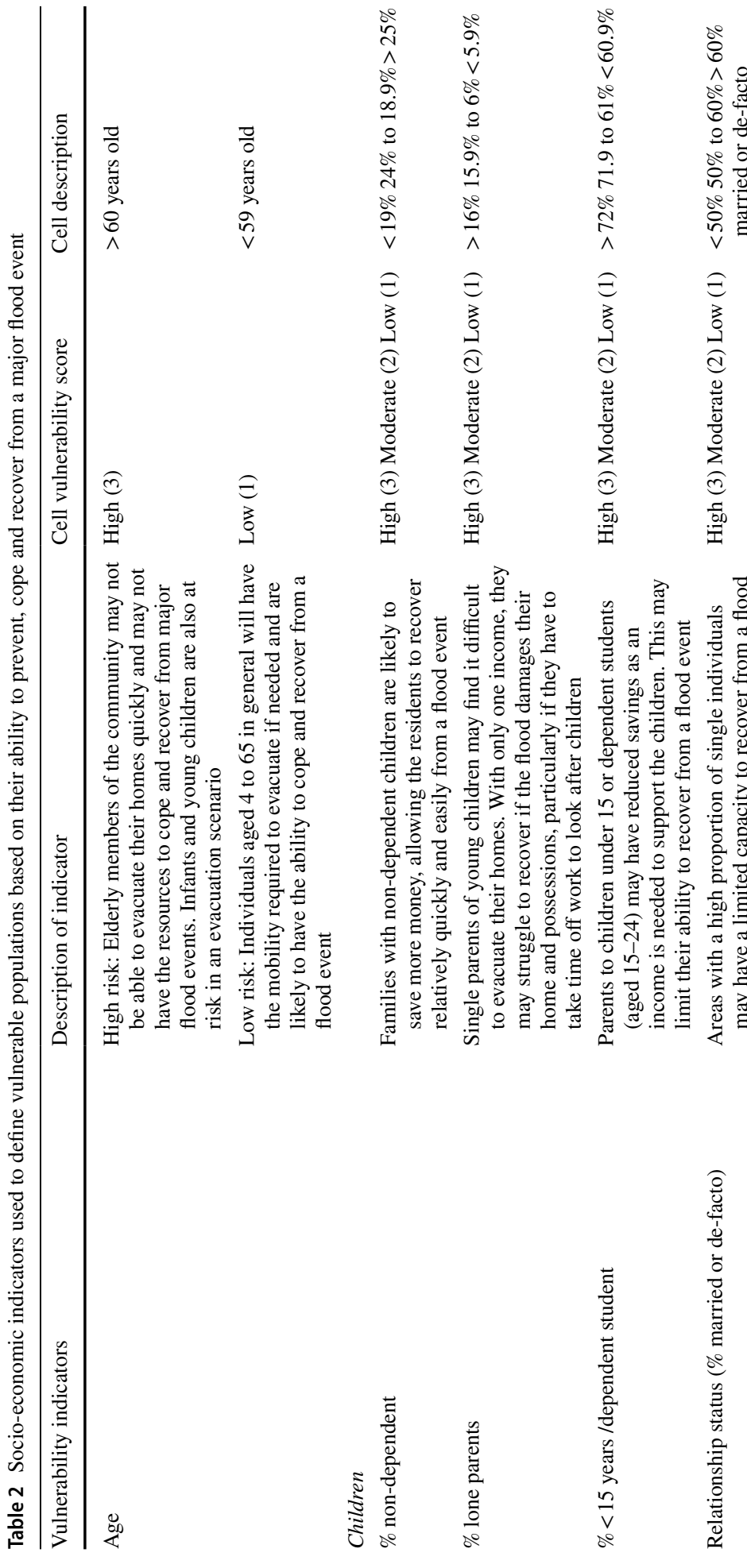

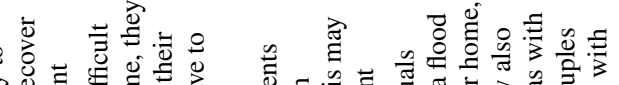

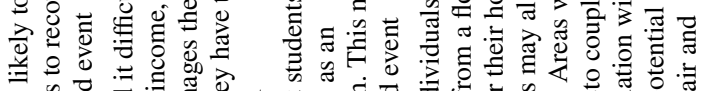

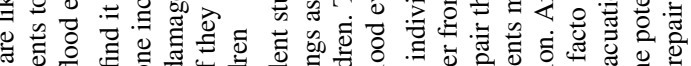
击

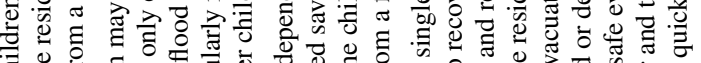

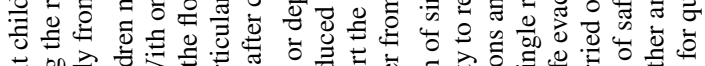

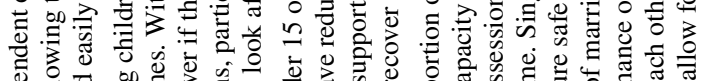

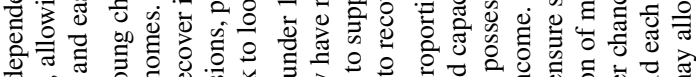
话元

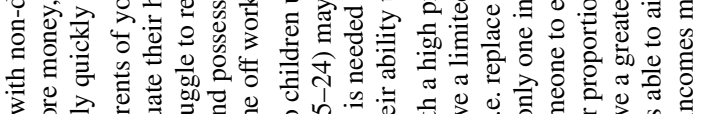

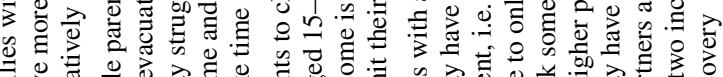

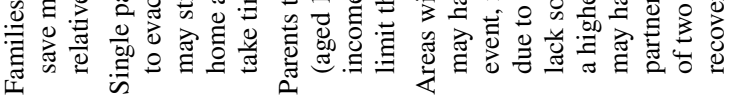

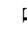
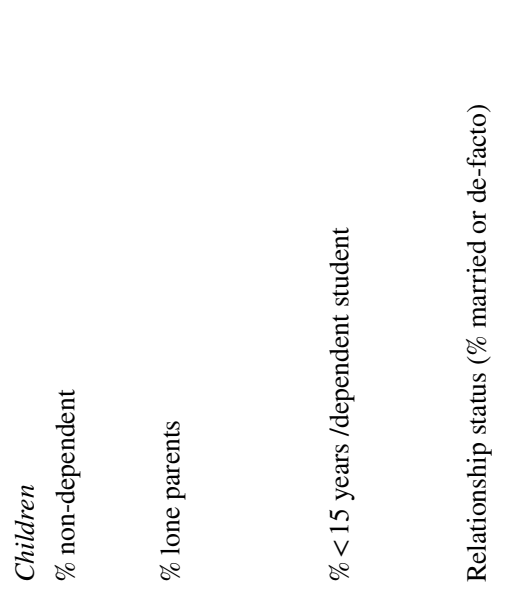


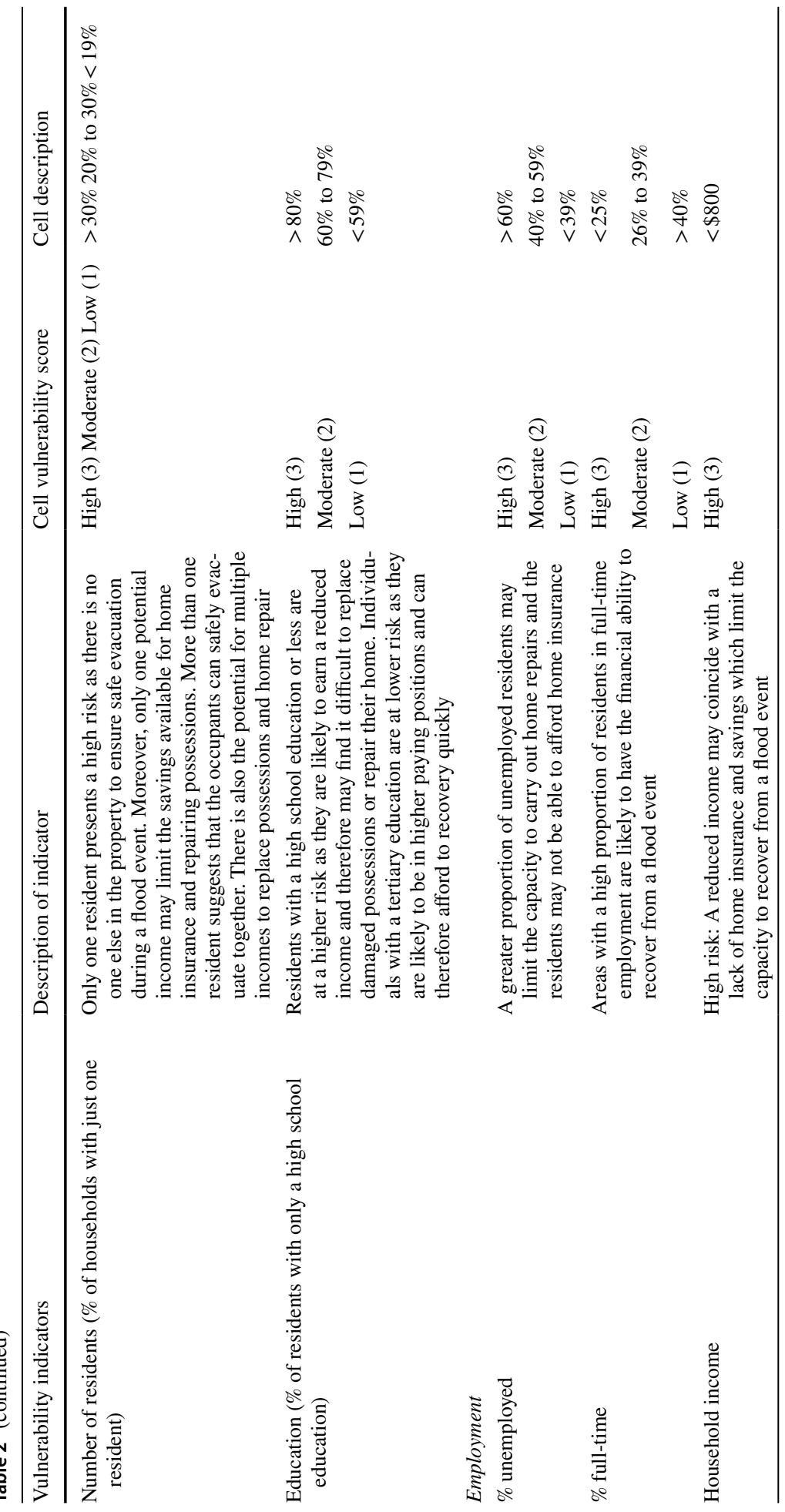




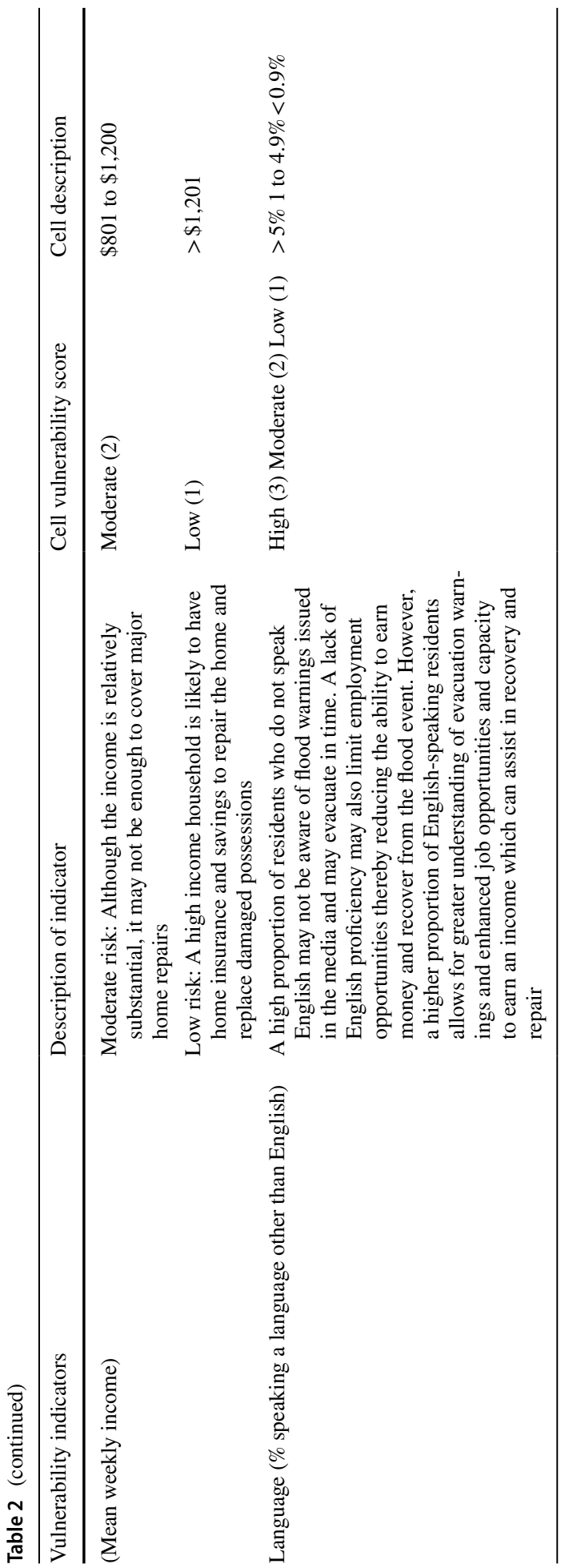




\subsection{Flood exposure}

Flood exposure mapping used spatial data layers acquired from the Landsat land cover mapping to identify urban localities. Urban density was calculated by overlaying a 1 ha grid onto the $30 \mathrm{~m}$ resolution land cover classification. The percentage of each cell occupied by urban land was extracted to provide a density score. The importance of infrastructure was also quantified using land cover mapping derived from Spatial Services Digital Topographic Database with high importance placed on critical services and residential areas. The complete criteria for exposure are detailed in Table 3.

The final flood exposure map was derived using the raster calculator tool to add flood exposure indicator layers together. The resulting map had cell scores ranging between 7 , indicating high flood exposure, and 2, indicating low flood exposure.

\subsection{Flood risk}

Flood risk was determined by integrating flood hazard, vulnerability and exposure. To ensure that each layer contributed equally to the final flood risk map, the input flood hazard, vulnerability and exposure maps were scaled to have scores between 1 and 10; this ensured that no input layer had a greater weighting than another. The inclusion of census data at SA1 scale resulted in boundaries between census units becoming an artefact in the final vulnerability map. Accordingly, a flood risk map that included flood hazard and exposure, whilst excluding flood vulnerability was also prepared which indicated biophysical data with infrastructure exposure alone, thereby preventing census boundaries from being inherited in the flood risk assessment.

\subsection{Land cover change}

Over the 30-year study period (1987-2017), the study area experienced an $80 \%$ increase in (peri)urbanisation from 14.45 to $25.98 \mathrm{~km}^{2}$ (Fig. 3, Table 4). This conversion to peri-urban and urban land has predominantly been at the expense of uncultivated remnant land (6.44 $\mathrm{km}^{2}$ ) and cultivated farmland $\left(3.06 \mathrm{~km}^{2}\right)$. The cultivated land which has been converted to urban land is primarily on bedrock associated with the Sydney Basin (Table 5), and is characterised as having relatively low elevation and moderate slope (mean elevation $=24.8 \mathrm{~m}$, mean slope $=3.6^{\circ}$ ). Uncultivated land that was converted to urban area is largely associated with estuarine sediments $(57 \%)$ or low elevation (mean elevation $=9.7 \mathrm{~m}$ ) and slope (mean slope $\left.=4.1^{\circ}\right)($ Table 5). Where converted uncultivated land was associated with bedrock geology, the elevation was typically higher (mean elevation $=29.6 \mathrm{~m}$ ), but was still of low slope $\left(\right.$ mean slope $=3.7^{\circ}$ ) $($ Table 5 ). The majority of urbanisation has occurred along the northern shoreline of St Georges Basin, within the suburbs of Basin View, St Georges Basin and Sanctuary Point. Significant peri-urbanisation also occurred along Sussex Inlet Road and was associated with the conversion of cultivated farmland.

Cultivated land also increased by $30 \%$ over the 30-year study period (an increase of $5.2 \mathrm{~km}^{2}$ ). Whilst some cultivated land was converted to urban areas, the increase in cultivated land was achieved through the conversion of uncultivated remnant land on bedrock geology, of relatively high elevation (mean elevation $=43.0 \mathrm{~m}$ ) and moderate slope (mean slope $=3 \cdot 0^{\circ}$. Over the study period, urban areas and cultivated land were characterised by 


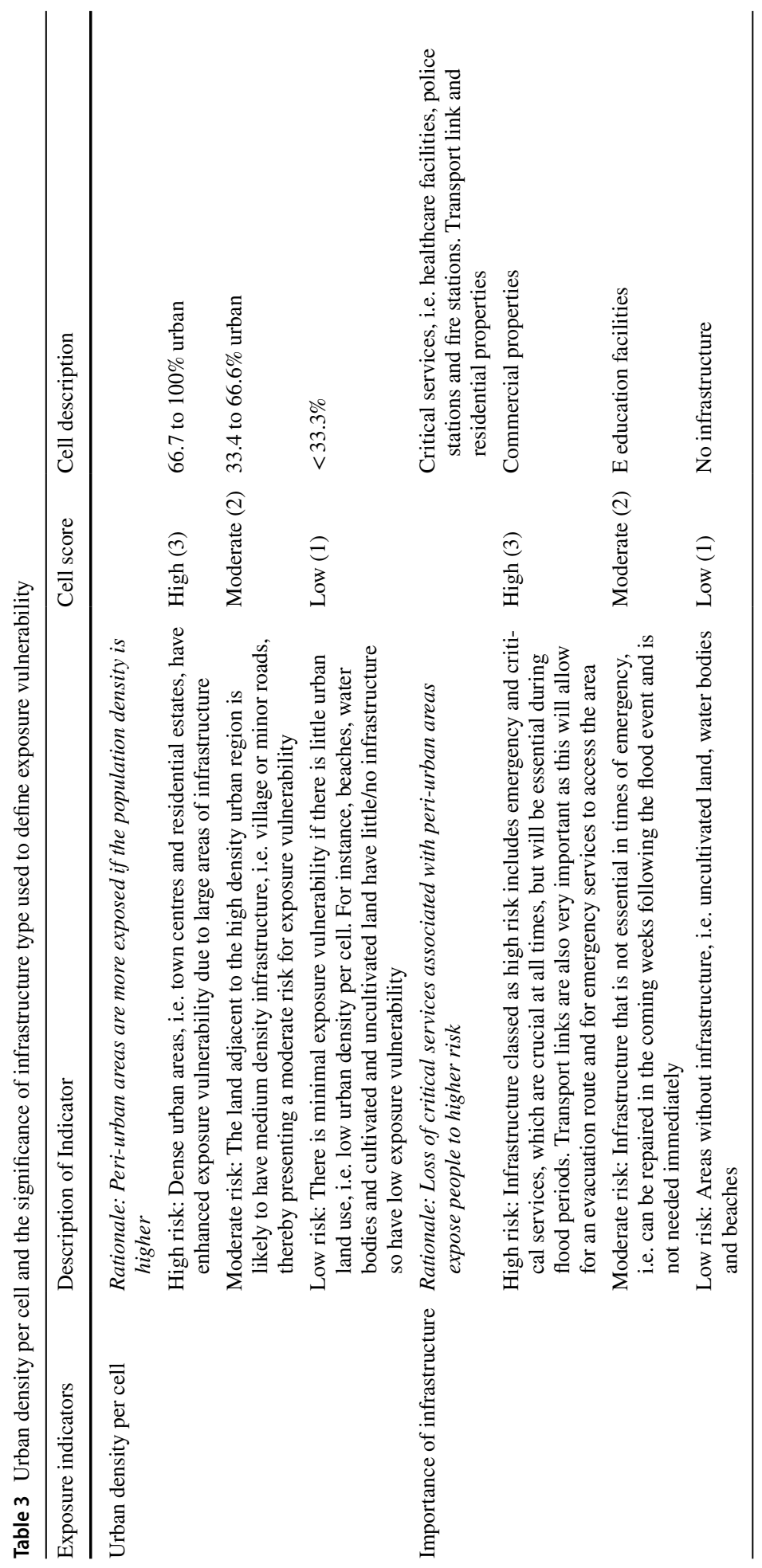



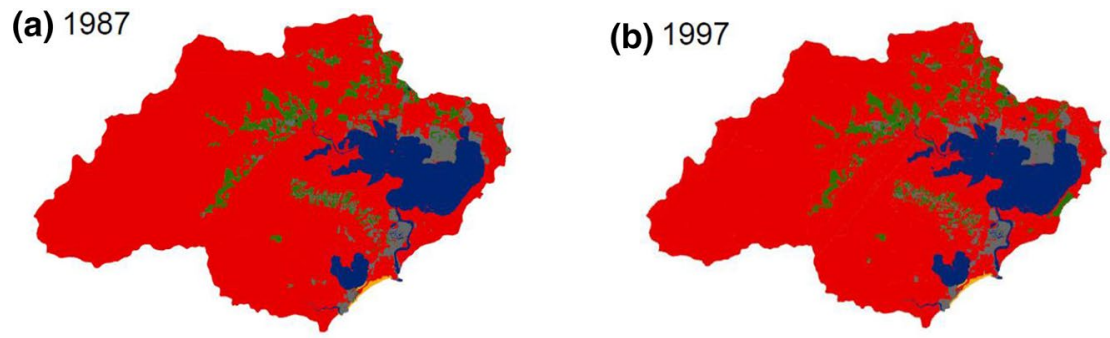

(c) 2007

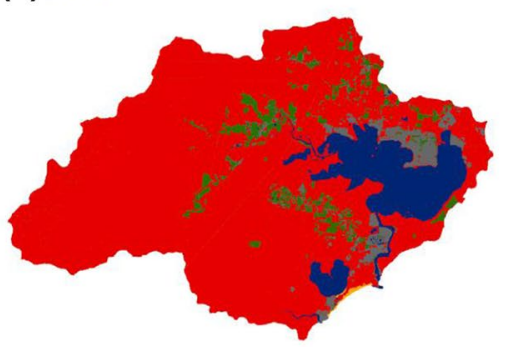

(d) 2017

(e)
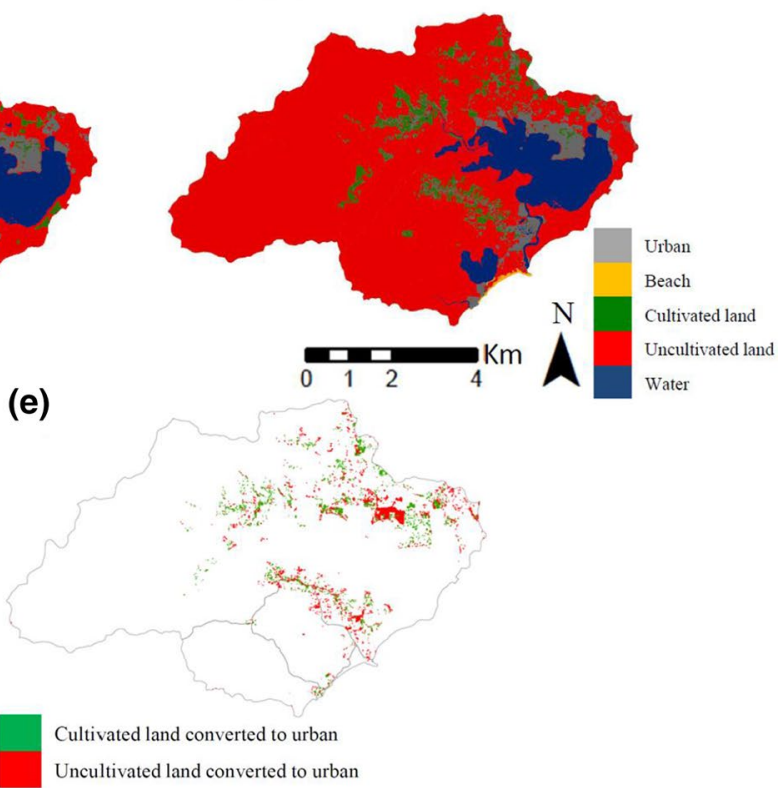

Fig. 3 Decadal changes in land cover for the St Georges Basin plus region a 1987, b 1997, c 2007, d 2017 and $\mathbf{e}$ areas converted to urban land between 1987 and 2017

Table 4 The area $\left(\mathrm{km}^{2}\right)$ of the five major land cover types (water, cultivated land, urban and uncultivated land) in 1987, 1997, 2007 and 2017 and the associated percentage of each land cover type within a high, medium and low vulnerable zone

\begin{tabular}{lrrrrl}
\hline Land cover type & \multicolumn{1}{c}{1987} & \multicolumn{1}{c}{1997} & \multicolumn{1}{c}{2007} & \multicolumn{1}{c}{2017} & 1987 to 2017 loss or gain \\
\hline Urban & 14.45 & 18.68 & 21.61 & 25.98 & +11.53 \\
Beach & 0.74 & 0.73 & 0.71 & 0.73 & No-significance \\
Cultivated land (farmland) & 21.80 & 23.95 & 25.46 & 26.98 & +5.18 \\
Uncultivated land & 346.52 & 340.03 & 339.58 & 331.81 & -14.71 \\
Water & 134.54 & 134.66 & 130.69 & 132.55 & -1.99 \\
\hline
\end{tabular}

low slopes; however, there was a temporal pattern of urban expansion into low elevation cultivated land, whilst cultivated land was progressively located at higher elevations within the study area. 


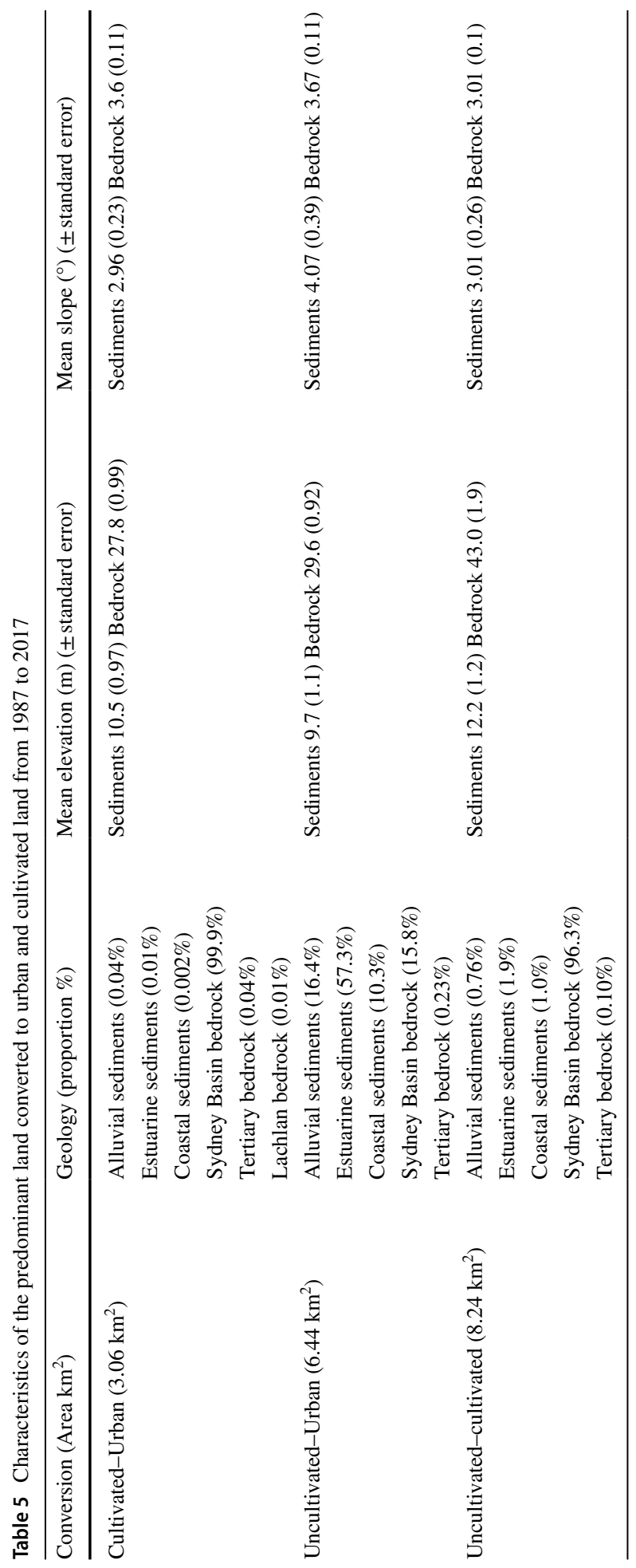




\subsection{Flood hazard}

Preliminary flood hazard analysis indicated that high hazard areas were associated with regions of low elevation $(<1 \mathrm{~m})$ and were primarily along the coastline of Cudmirrah and Berrara, and on the shoreline of St Georges Basin, particularly near Sussex Inlet. Regions of low hazard were generally further inland and included parts of Wandandian, the canal estates at Sussex Inlet and north of Swan Lake. The majority of the study area was regarded to be of low flood hazard ( $>5 \mathrm{~m}$ elevation). National Parks (Conjola and Jerrawangala) constituted the major areas where slope exceeded $4^{\circ}$; however, parts of the northern shoreline of St Georges Basin near Basin View and St Georges Basin (town) also exhibited high slopes that would offset their flood hazard. Low slope regions $\left(<2^{\circ}\right)$ occurred where water was already known to accumulate including the canal estates of Sussex Inlet, and parts of Wandandian, Bewong and Sussex Inlet. Depressions, where water could accumulate, were found throughout the study area. Shallow depressions were regarded to be of higher hazard as they would fill rapidly, whilst deeper depressions were regarded to be less hazardous as they could store more water and take longer to fill.

The flood hazard map was generated by summing the standardized index values for elevation, slope, land depression and land cover spatial data (Fig. 4). This analysis indicated that urban areas of Wandandian, Bewong, Sussex Inlet and Cudmirrah, followed by Sanctuary Point and Erowal Bay, were amongst the areas with the highest flood hazard. Due to the high elevation and high slope characteristics of national parks and state forests within the study area, uncultivated land was regarded to have the lowest flood hazard.

\subsection{Flood vulnerability}

Figure 5a-h shows all the separate socio-economic indicators used to generate the flood vulnerability map (Fig. 5i). Worrowing Heights was found to have the highest vulnerability score when combined (labelled V in Fig. 5i); this is not surprising as the suburb scores a high hazard in all individual indicators, except regarding children and relationship status. This is likely to be due to the presence of a large age care facility and nursing home with a high population of single elderly residents, with a low income and high unemployment. The suburbs of least concern are Wandandian, Tomerong, Jerrawangala and Jervis Bay labelled W, X, Y and Z, respectively, in Fig. 5i, with a high proportion of residents in fulltime employment, more than one resident per household, below 59 years old and a relatively high mean weekly income. The only indicators representative of a high hazard are related to the popularity of these particular suburbs for tourism and commuter individuals and families. The residents of these suburbs include young single professionals (i.e. high proportion of single resident properties) and families with dependent children currently in high school education.

\subsubsection{Flood exposure}

A strong spatial correlation between urban density (Fig. 6a) and the importance of infrastructure (Fig. 6b) was evident, and accordingly resulted in higher flood exposure (Fig. 6c). The essential services that increased flood exposure in urban areas such as Sussex Inlet, Sanctuary Point, Erowal Bay and Basin View included energy corridors, substations, roads 

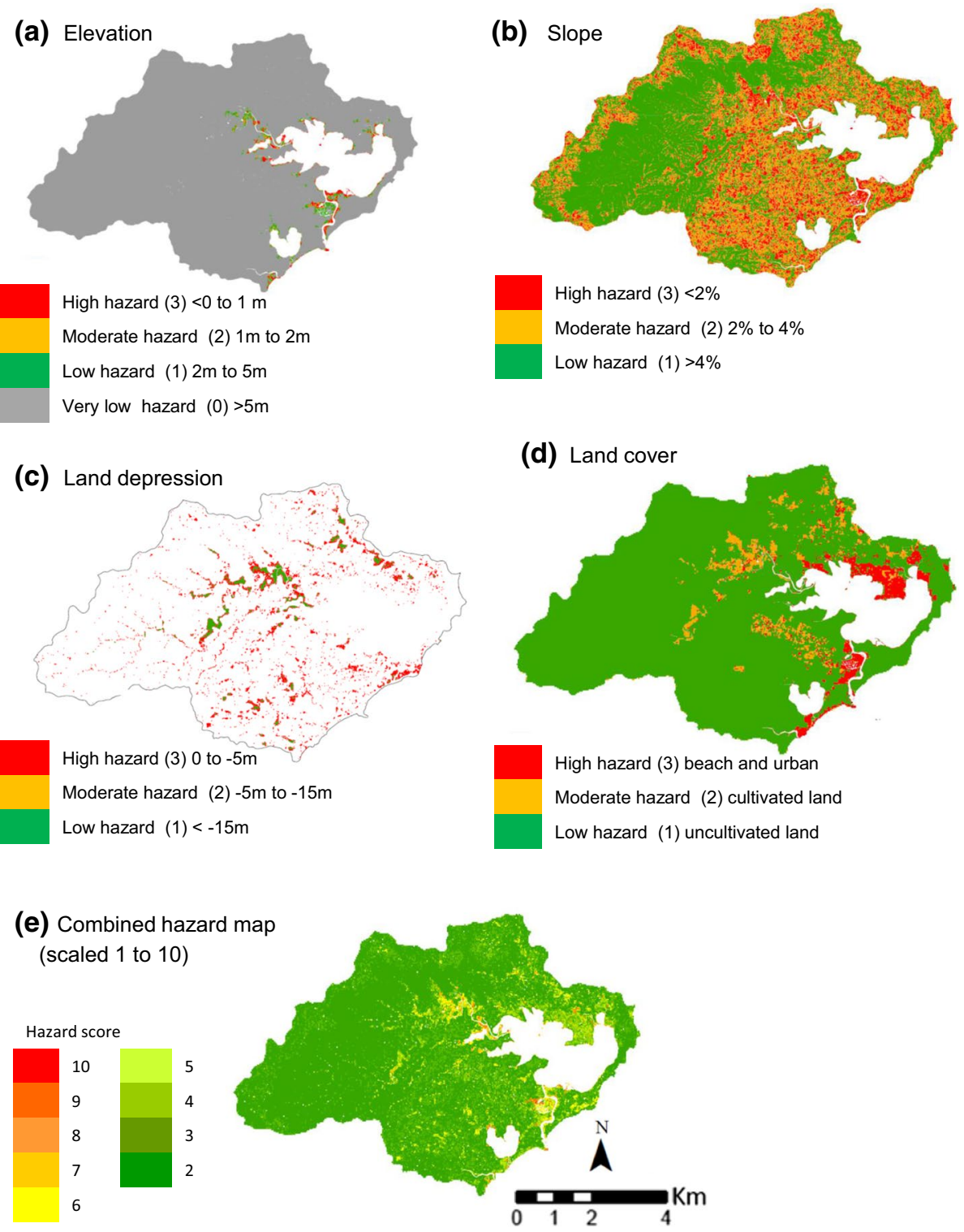

Fig. 4 Flood hazard mapping a elevation, $\mathbf{b}$ slope, $\mathbf{c}$ land depression, $\mathbf{d}$ land cover and $\mathbf{e}$ combined map

and residential properties. Regions with infrastructure of moderate importance were generally located on the outskirts of suburbs, whilst regions with low infrastructure importance were associated with uncultivated or cultivated land located distal from the urban centres. 


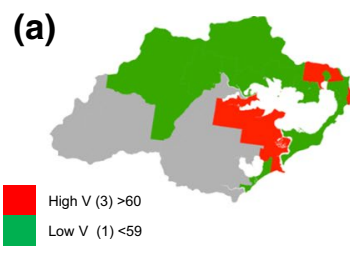

(d)

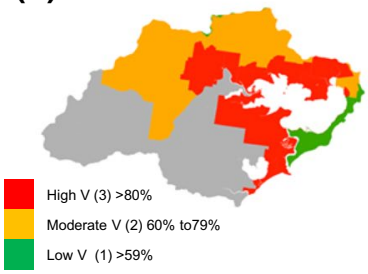

(g)

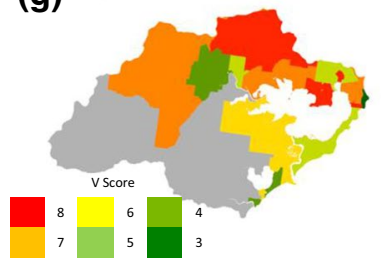

(b)

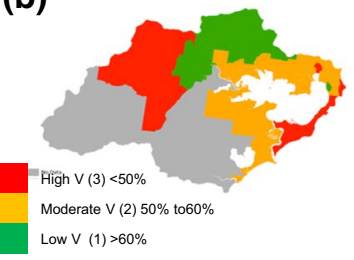

(e)

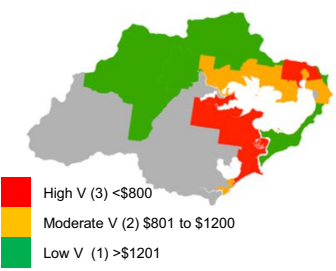

(c)

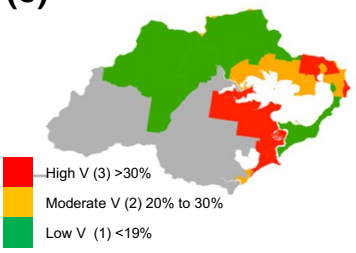

(f)

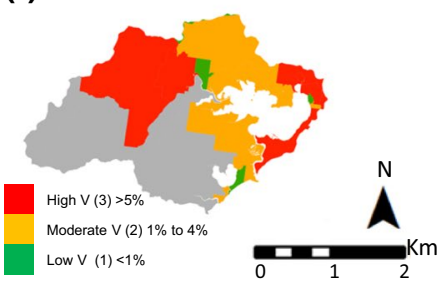

(i)

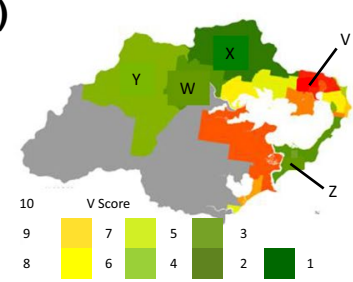

Fig. 5 Social vulnerability (V) using socio-economic data derived for state suburbs from 2016 Census data (grey colouring indicates areas with no available census data): a Age, $\mathbf{b}$ relationship status (\% married or de-facto), $\mathbf{c}$ number of residents (\% of households with just one resident), $\mathbf{d}$ education (\% of residents with only a high school education, $\mathbf{e}$ household income (mean weekly income), f language (\% speaking a language other than English), $\mathbf{g}$ children: a combination of the percentage of lone parents, children under 15 years old, dependent students and percentage of non-dependent children, $\mathbf{h}$ employment (combined percentage of full-time employment and unemployment) and n) vulnerability combined. Worrowing Heights is identified by the ' $\mathrm{V}$ ' and Wandandian, Tomerong, Jerrawangala and Jervis Bay are labelled W, X, Y and Z, respectively

\subsubsection{Flood risk}

By combining flood hazard, vulnerability and exposure, areas of high flood risk were found to include Sussex Inlet, particularly near the canal estates, Tullarwalla, Sanctuary Point and Old Erowal Bay, whilst areas with the lowest flood risk were uncultivated land associated with national parks and state forests (Fig. 7a). Due to the coarse resolution of socio-economic data derived from census data, suburb boundaries remained an artefact within the generated flood risk map. To determine the overall effect of this artefact on flood risk, exclusion of these data from the secondary flood risk map indicated that flood risk was more so associated with environmental gradients within biophysical factors such as elevation and slope (Fig. 7b). High infrastructure importance along Sussex Inlet Road remained obvious in the final flood risk map, reflecting the importance of this transport route in modulating flood risk, particularly for residents of Sussex Inlet. 


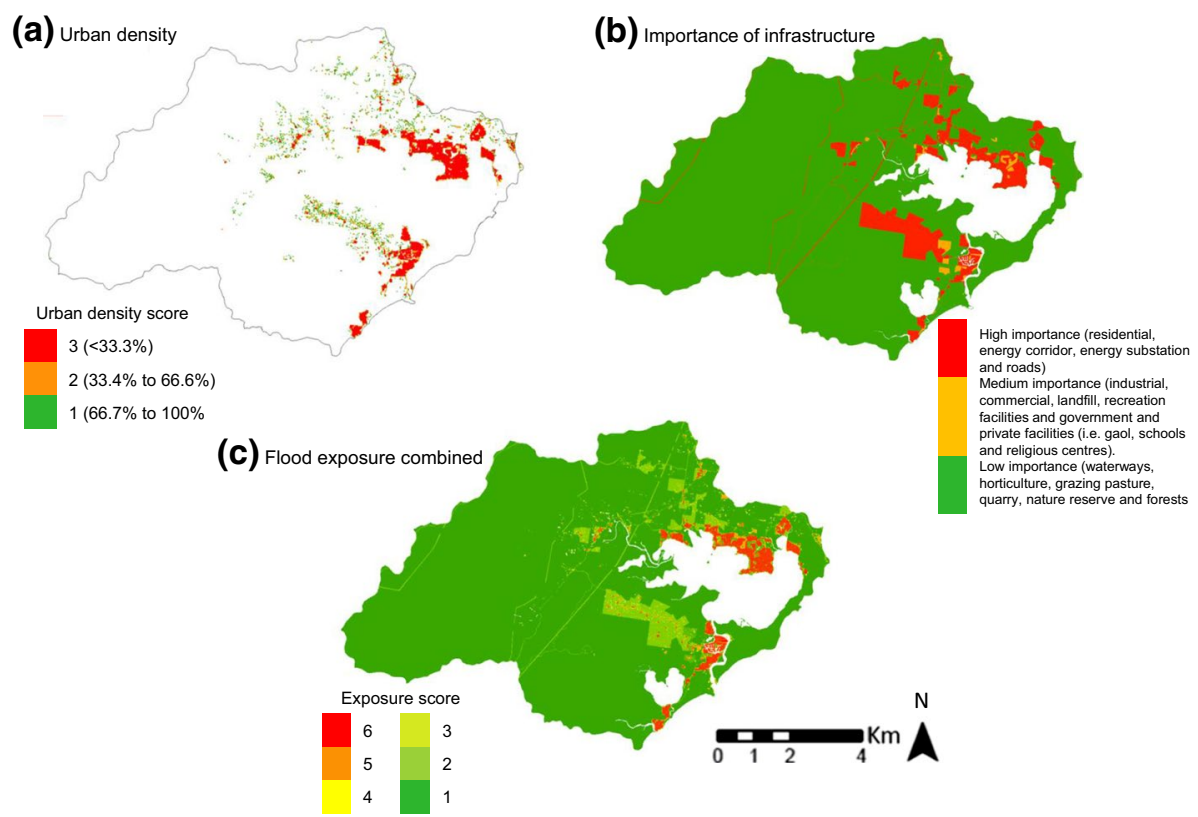

Fig. 6 Flood exposure a urban density, b importance of infrastructure and $\mathbf{c}$ flood exposure combined

\section{Discussion}

\subsection{Landscape pattern of peri-urbanisation}

The PUI of Sussex Inlet District offers a semi-rural lifestyle with highly valued natural capital assets within commuting distance of growing urban centres such as Nowra and Wollongong, and it is likely these factors contributed to population increase over the study period from 3167 in 1991 to 4247 in $2016(+1080)$. To accommodate this growing population, land cover mapping indicated that there has been an $80 \%$ increase in urban areas, including peri-urban areas, and 30\% increase in cultivated land. Incongruously, the natural capital of the study area that likely contributed to population increase over the study period, mapped as uncultivated land, beaches and water, exhibited an almost equivalent decline in extent as the increase in (peri)urban and cultivated land. Accordingly, desires for connection with natural landscapes that results in increasing PUI as people seek a 'sea-change' or 'treechange' lifestyle are driving a decline in the natural landscape values that they are seeking.

The observed pattern of PUI expansion was not atypical and occurred in close proximity to existing PUI, transport links and infrastructure. Where cultivated land was converted to (peri) urban land use, slope and elevation were not deemed to contribute to flood hazard, and it was considered unlikely that new (peri)urban areas were exposed to high flood hazard. However, the analysis of land use change did indicate that the incremental pattern of (peri)urban expansion and displacement of cultivated land into previously uncultivated areas may not be leveraging landscape factors to optimise land use efficiency. Whilst PUI expansion into previously cultivated land had a higher elevation and similar slope to (peri)urban areas that were not converted over the study period, areas converted from uncultivated to cultivated land had a higher 


\section{(a)}

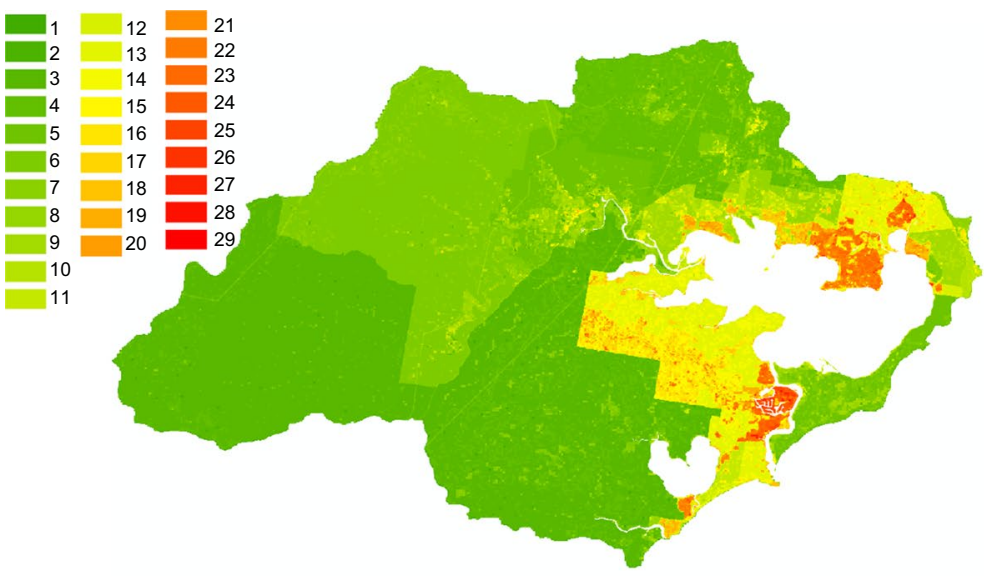

(b)

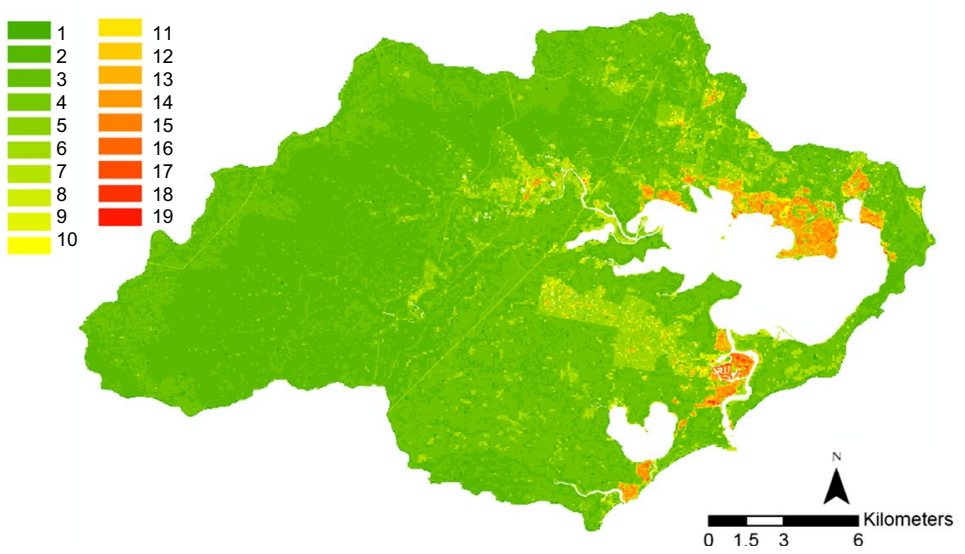

Fig. 7 a Flood risk map generated by integrating flood hazard, vulnerability and exposure; b Flood risk map generated by integrating flood hazard and exposure, whilst excluding flood vulnerability to eliminate inherited suburb boundaries in the final map

slope and elevation than cultivated areas that were not converted over the study period. Additionally, as soil development from the sandstones of the Sydney Basin produces soils with low fertility (Leishman and Thomson 2005), this displacement meant that a greater proportion of newer cultivated land was situated on less fertile soils, rather than the more fertile sediments that accumulated on alluvial and coastal floodplains. Accordingly planning decisions that minimise flood hazard as the PUI foot print increases are displacing rural activities to less suitable landscapes. 


\section{2 (Peri)urbanisation flood risk}

Our analysis of flood hazard indicated that the biophysical aspects of flood risk were concentrated around low-lying areas associated with the townships of Wandandian, Bewong, Sussex Inlet and Cudmirrah. This is not surprising given the desire for housing to occur on low slope land that provides ease of access and offers considerable slope stability. However, flood risk assessments that focus solely upon biophysical aspects of flooding have been criticised as they do not explicitly indicate the values or assets that are at risk, or consider a wider range of variables that contribute to the risk of these values/assets. In this study we aimed to establish the flooding risk for communities in the PUI associated with Sussex Inlet and St Georges Basin. Mapping the spatial vulnerability of communities in response to extreme hazards has been the focus of numerous studies (Chakraborty et al. 2005; Kaźmierczak and Cavan 2011; Lindley et al. 2006; Nelson et al. 2010) and frameworks have been suggested by Udale-Clarke et al. (2005) to guide spatial mapping of flood risk. Often these approaches only take into account the initial impact of the event and the immediate danger to residents, e.g. drowning. Instead, vulnerability assessments need to spatially identify members of the community who are more susceptible to direct harm and damage and who are at risk long-term as they struggle to recover as a consequence of their socio-economic status (Clark et al. 1998).

This study modified the risk triangle frame work to incorporate and weight a range of demographic factors that may indicate those members of the community who are more susceptible to harm associated with flooding. We also acknowledge the limitation of social vulnerability assessments relying on census data because these do not account for social capital inherent to specific communities that can provide important support for both flood response and recovery; nor for human behaviour dynamics that can change risk profiles (Chamlee-Wright and Storr 2009; Aerts et al. 2018). By incorporating demographic indicators of vulnerability into this assessment, our results suggest that the community of Sussex Inlet and District are vulnerable to extreme flood events, due in large part to their ageing population. Nearby urban centres of Nowra and Wollongong exhibit a greater concentration of young professionals without children as they provide greater employment opportunities, improved transport networks and recreational/entertainment activities. Whilst some economic benefits are provided to the community of Sussex Inlet due to the influx of visitors in summer months, this benefit is quickly offset through winter when holiday homes are vacant and income to the region becomes depleted. On the other hand, the significant influx of visitors during the summer and holiday periods presents considerable challenges to emergency services should flood events occur because of their lack of experience with local flood risk. In contrast, Tullarwalla, Jerrawangala, Tomerong and Yerrigong, located further from the more densely populated areas of Sussex Inlet, Sanctuary Point and Worrowing Heights, are characterised by reduced vulnerability. These townships, located closer to the Princes Highway, the main transport route to the urban centres of Nowra and Wollongong, support a higher proportion of families, as opposed to the ageing populations that dominate the more populous areas.

Whilst the vulnerability assessment provided greater insight into flood risk, some drawbacks remained that primarily related to the spatial resolution of demographic data. Biophysical data derived from remote sensing are dependent upon the resolution of sensors fixed to satellites, aircraft or drones, with the typical pixel size now expected to be less than $30 \mathrm{~m}$ (i.e. the pixel size of Landsat and SRTM data). In contrast, demographic data that can be used to indicate socio-economic composition of communities are commonly 
derived from census data, which are limited in spatial resolution due to a need to maintain individual privacy. In this study we used census data at the suburb scale, which provided an indication of the mean and range in various indicators of vulnerability. This approach does not provide an indication of the extreme demographic outliers in the community that will include those people that have the highest and lowest levels of vulnerability (e.g. the vulnerability of a highly mobile young professional family will be inaccurately indicated as high if they reside in an ageing community). The low resolution of socio-economic data in this study resulted in suburb boundaries being conspicuous in the final risk assessment. To address this issue, we propose separating vulnerability from the flood risk map and assessing risk on the basis of both the vulnerability map and integrated flood hazard and exposure map.

\subsection{Factors contributing to (peri)urban flood risk}

By interpreting both the flood vulnerability and integrated flood hazard/exposure maps, this study found that the Sussex Inlet urban centre exhibited was the highest flood risk of urban centres in the study area. This contrasts the prevailing view of many residents that the occurrence of canals in the town affords some protection due to their capacity to store flood waters (pers comm.). These popular views are at odds with the results of the biophysical analyses and are further offset by the demography of the town. More specifically, the biophysical flood hazard assessment demonstrates that the township is low lying and canals create a network for transport of water throughout the township resulting in more of the community associated with a shoreline and therefore at risk. In addition, the community was characterised to be more vulnerable by virtue of their demography (i.e. ageing population with a median age of 60); and the concentration of people and high value infrastructure in this region increases the exposure of the community to flood risk. This exposure is further affected by a single transport route from the township to Princes Highway and the nearest urban centres (i.e. Sussex Inlet Road). Other townships exhibiting moderately high vulnerability included the Sanctuary Point and Worrowing Heights. Here the biophysical flood hazard was not as high as elsewhere (e.g. Sussex inlet and Wandandian); however, demographic factors of flood vulnerability owing to the ageing population of low income significantly contributed to the flood risk scoring.

\subsection{Planning and managing peri-urban flood risk}

Ageing or commuter communities seeking sea-change or tree-change lifestyles will create greater pressure for peri-urban expansion in regions such as Sussex Inlet and St Georges Basin, and this analysis indicates that this implicitly contributes to their flood risk, particularly as they seek residences with sea views on low-lying low slope land where infrastructure is available. Population projections for the Shoalhaven region forecast a $24.06 \%$ growth in population from 101,970 in 2016 to 128,733 in 2041 (based on 2016 census data, resource: https://forecast.id.com.au/shoalhaven/population-summary), and this will create considerable complexity for planners tasked with accommodating the lifestyle desires of incoming 'changers' whilst maximising landscape values for existing non-urban land uses. Climate change and associated sea-level rise will compound this complexity with sea-level rise and temperature increases accelerating in the future with the degree varying on the basis of future scenarios or RCPs (IPCC 2013). 
The risk triangle framework was adapted to incorporate climate change and changing population demographics to map peri-urban flood risk and identify factors contributing to flood risk (Fig. 8a), and by abstraction can feasibly be used to inform planning and management options that minimise future flood risk associated with peri-urbanisation. In this regard risk minimisation would be seeking to mitigate factors that increase flood hazard, exposure and/or vulnerability, whilst accounting for projected climate and demographic change. Applying a business as usual scenario to planning that was based on past patterns of peri-urban expansion in the region would see all sides on the risk triangle increase, and flood risk increase accordingly. This scenario is not unreasonable given future demographic and climate change projections indicate that we have already committed to increasing flood risk in the region. More specifically, the combined effects of sea-level rise and increasing rainfall will exacerbate the frequency and extent of nuisance flooding, and based on the previous characteristic 'sea-change' and 'tree-change' demographic patterns, this business as usually scenario would increase the exposure of populations to flooding, and ultimate increase flood risk (Fig. 8b).

Planning should ultimately seek to minimise risk and given the current commitment to at least $0.38 \mathrm{~m}$ of sea-level rise and $2{ }^{\circ} \mathrm{C}$ of warming, even drastic action to mitigate climate change by reducing atmospheric carbon concentrations will still result in an increase in flood risk. However, there are some planning and management strategies that could feasibly
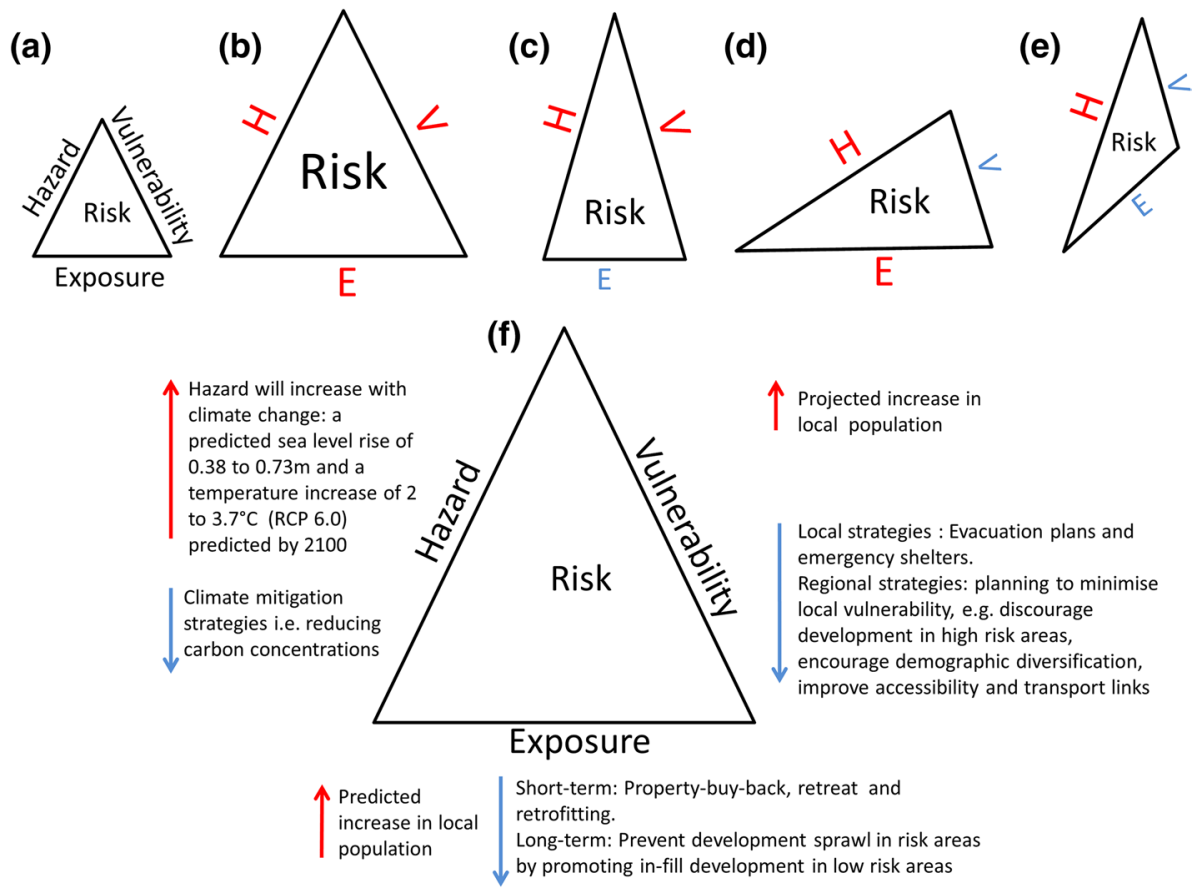

Fig. 8 Conceptual diagram indicating how the a risk triangle framework can be used to aid planning and management to minimise flood risk, considering a range of possible futures, such as $\mathbf{b}$ a business as usual scenario where all sides of the triangle increase; and approaches that reduce the overall risk by minimising $\mathbf{c}$ exposure, $\mathbf{d}$ vulnerability and $\mathbf{e}$ both exposure and vulnerability. This provides the means to consider f future management and planning strategies that reduce the rate of increase in flood risk due to climate change and increasing population pressure 
minimise the rate of increasing flood risk with climate change. One strategy is to specifically target reducing the exposure (Fig. 8c) through property buyback or land swap schemes (DIPNR 2005), retreat from high hazard areas and retrofitting of at-risk infrastructure and dwellings can effectively minimise flood exposure at a local scale. These responses, however, may not be financially viable over longer planning horizons of 50-100 years and at the regional scale and do not address the future need to accommodate population increases. Given the difficulty in reversing the extent of (peri)urbanisation in the region, some may argue that reducing flood exposure may not be a feasible long-term strategy.

However, with endorsement by higher levels of the government through coastal planning policies (Coastal Management Act, 2016 and Coastal Management SEPP) and the increasing need to manage the cumulative risks (flood and coastal inundation, drought and fire) NSW strategic land use planning and local council coastal management plans are able to manage future developments within Shoalhaven. The management plans, policies and legislations are designed to balance the needs of the local community and economy for a changing demographic and population, whilst maintaining the coastal environment and associated ecosystems. As such, the existing management protocols have the potential to improve the planning and assessment of coastal developments in Sussex Inlet to manage for current and future hazards and protect coastal and marine assets. In this way, the flood exposure and subsequent flood risk could be managed through careful land use planning by NSW government and Shoalhaven Council. Proactive strategies that could be implemented to reduce the rate of increase in flood exposure include preventing further developments in flood risk areas and encouraging population density to increase within the current peri-urban footprint by increasing dwelling density. However, given the current characteristic 'sea-change' demography of the region, this strategy may not be appealing to the community.

Altering the factors contributing to flood vulnerability (Fig. 8d) can be implemented at the local scale by developing adaptation strategies, such as increased community participation in emergency planning, increased redundancy of evacuation routes and options of shelters for residents in areas of high risk. Implementation of strategies that are effective at the scale of the region or urban centre would require careful planning that alters patterns of demographic change within the region, a factor that can feasibly be achieved with planning. For example, development of transport links that improve accessibility to larger centres creates a commuter corridor and can foster local business development that would create new employment opportunities, as well as function as evacuation routes. As climate change will increase flood hazard, strategies that reduce flood exposure and vulnerability will be more effective at reducing flood risk (Fig. 8e). From a planning and emergency management perspective, it is also imperative to consider a multi-hazards risk approach when implementing adaptation strategies. Care should be taken to ensure that planning interventions to mitigate flood risks do not result in an increase in other hazards. The study area, for example, also has high vulnerability to wildfires which are likely to be exacerbated under climate change (Hennessy et al. 2005; Bardsley et al. 2018).

\section{Conclusion}

Planning for hazards and risks in peri-urban areas has received little attention, despite an increasing need to accommodate rural priorities, urban growth and an expanding periurban population. In this paper we have addressed this knowledge gap by developing flood risk maps for a peri-urban area by adapting the risk triangle framework to incorporate 
sea-level rise and changing population demographics. This study demonstrates the insights gained from flood risk visualisation and being able to explicitly interpret factors contributing to flood risk. The approach does not assume all indicators of flood risk are equal in terms of significance and driving power and as such provides a novel opportunity to develop a consistent approach to mapping risk, which can be applied across spatial scales using high resolution remotely sensed data and products. By mapping flood risk using an indicator-based approach, we found that the Sussex Inlet township exhibited the highest flood risk of all urban centres in our study area due largely to the influence of the low-lying nature of the township, conveyance of flood waters throughout canals and the demographic character of the community which increased flood hazard and exposure. Integrating the flood risk triangle with future scenarios of demographic and climate change, and considering factors that contribute to peri-urban flood risk, facilitated the identification of planning strategies that would reduce the future rate of increase in flood risk, such as increasing urban density using multi-storey dwellings, and fostering local business development. The maps generated in this study constitute useful information for decision makers tasked with planning and managing flood risk in the region, and the approach can be used to improve planning strategies (such as the Coastal Management Act, 2016 and Coastal Management SEPP) to minimise flood risk in peri-urban areas.

\section{References}

ABS (2016) 2916.0-Census of Population and Housing-QuickStats, Community Profiles and DataPacks User Guide, Australia, 2016 . Australian Bureau of Statistics. Accessed at : https://www.abs.gov.au/ websitedbs/D3310114.nsf/Home/Census? OpenDocument\&ref=topBar

Aerts JCJH, Botzen WJ, Clarke KC, Cutter SL, Hall JW, Merz B, Michel-Kerjan E, Mysiak J, Surminski S, Kunreuther H (2018) Integrating human behaviour dynamics into flood disaster risk assessment. Nat Clim Chang 8(3):193-199

Allen A (2003) Environmental planning and management of the peri-urban interface: perspectives on an emerging field. Environ Urban 15(1):135-148

Bardsley DK, Moskwa E, Weber D, Robinson GM, Waschl N, Bardsley AM (2018) Climate change bushfire risk, and environmental values: examining a potential risk perception threshold in Periurban South Australia. Soc Nat Resour 31(4):424-441

Bernard A, Charles-Edwards E, Alvarez M, Wohland P, Loginova J, Kalemba S (2020) Anticipating the impact of COVID-19 on internal migration. Centre for Population Research Paper, The Australian Government, Canberra

Bruneau M, Chang SE, Eguchi RT, Lee GC, O'Rourke TD, Reinhorn AM, Shinozuka M, Tierney KT, Wallace WA, von Winterfeldt D (2003) A framework to quantitatively assess and enhance the seismic resilience of communities. Earthq Spectra 19(4):733-752

Burnley IH, Murphy PA (1995) Exurban development in Australia and the United States: through a glass darkly. J Plan Educ Res 14(4):245-254

Burnley IH, Murphy P (2004) Sea change: movement from metropolitan to arcadian Australia. UNSW Press

Buxton M, Choy DL (2007) Change in peri-urban Australia: implications for land use policies. State of Australian Cities' Conference. Brisbane, Adelaide, pp 28-30

Chakraborty J, Tobin GA, Montz BE (2005) Population evacuation: assessing spatial variability in geophysical risk and social vulnerability to natural hazards. Nat Hazard Rev 6(1):23-33

Chamlee-Wright E, Storr V (2009) "There's No Place Like New Orleans": sense of place and community recovery in the ninth ward after hurricane katrina. J Urban Aff 31(5):615-634

Clark GE, Moser SC, Ratick SJ, Dow K, Meyer WB, Emani S, Jin W, Kasperson JX, Kasperson RE, Schwarz HE (1998) Assessing the vulnerability of coastal communities to extreme storms: the case of revere, MA USA. Mitig Adapt Strateg Global Change 3:59-82

Crichton D (1999) The risk triangle. Nat Disaster Manag 102:103 
Cutter SL, Burton CG, Emrich CT (2010) Disaster resilience indicators for benchmarking baseline conditions. J Homel Secur Emerg Manag. https://doi.org/10.2202/1547-7355.1732

Department of Infrastructure, Planning and Natural Resources (DIPNR) (2005) NSW Floodplain Development Manual. New South Wales Government, Sydney, Australia

Douglas I (2012) Peri-urban ecosystems and societies: transitional zones and contrasting values. Routledge, The peri-urban interface, pp 41-52

Gosnell H, Abrams J (2011) Amenity migration: diverse conceptualizations of drivers, socioeconomic dimensions, and emerging challenges. GeoJournal 76(4):303-322

Granger K (2003) Quantifying storm tide risk in Cairns. Nat Hazards 30(2):165-185

Gurran N, Blakely E (2007) Suffer a sea change? contrasting perspectives towards urban policy and migration in coastal Australia. Aust Geogr 38(1):113-131

Hartnett M, Nash S (2017) High-resolution flood modeling of urban areas using MSN_Flood. Water Sci Eng 10(3):175-183

Hennessy K, Lucas C, Nicholls N, Bathols J, Suppiah R, Ricketts J (2005) Climate change impacts on fire-weather in south-east Australia. Consultancy report by CSIRO Marine and Atmospheric Research, Bureau of Meteorology and Bushfire CRC, p 88

Kaźmierczak A, Cavan G (2011) Surface water flooding risk to urban communities: analysis of vulnerability, hazard and exposure. Landsc Urban Plan 103(2):185-197

Leishman MR, Thomson VP (2005) Experimental evidence for the effects of additional water, nutrients and physical disturbance on invasive plants in low fertility Hawkesbury Sandstone soils Sydney, Australia. J Ecol 93(1):38-49

Lindley SJ, Handley JF, Theuray N, Peet E, McEvoy D (2006) Adaptation strategies for climate change in the urban environment: assessing climate change related risk in UK Urban Areas. J Risk Res 9(5):543-568

McSweeney S, Kennedy D, Rutherfurd I, Stout J (2017) Intermittently closed/open lakes and lagoons: their global distribution and boundary conditions. Geomorphology 292:142-152

Nelson AC, Dueker KJ (1990) The Exurbanization of America and its planning policy implications. J Plan Educ Res 9(2):91-100

Nelson R, Kokic P, Crimp S, Martin P, Meinke H, Howden S, de Voil P, Nidumolu U (2010) The vulnerability of Australian rural communities to climate variability and change: Part II-Integrating impacts with adaptive capacity. Environ Sci Policy 13(1):18-27

Nguyen TT, Bonetti J, Rogers K, Woodroffe CD (2016) Indicator-based assessment of climate-change impacts on coasts: a review of concepts, methodological approaches and vulnerability indices. Ocean Coast Manag 123:18-43

Norris FH, Stevens SP, Pfefferbaum B, Wyche KF, Pfefferbaum RL (2008) Community resilience as a metaphor, theory, set of capacities, and strategy for disaster readiness. Am J Community Psychol 41:127-150

Roy P, Williams R, Jones A, Yassini I, Gibbs P, Coates B, West R, Scanes P, Hudson J, Nichol S (2001) Structure and function of south-east Australian estuaries. Estuar Coast Shelf Sci 53(3):351-384

Saintilan N, Rogers K, Toms C, Stein ED, Jacobs D (2016) Intermittent estuaries: linking hydro-geomorphic context to climate change resilience. J Coastal Res 75(sp1):133-137

Wollondilly Shire Council (2021) Impact of COVID-19 on population growth. Available at: https://forec ast.id.com.au/wollondilly/forecast-covid19-impact

Simon D (2008) Urban environments: issues on the peri-urban fringe. Annu Rev Environ Resour 33(1):167-185

Stocker TF, Qin D, Plattner G-K, Tignor M, Allen SK, Boschung J, Nauels A, Xia Y, Bex V, Midgley PM (2013) Climate change 2013: The physical science basis. Intergovernmental Panel on Climate Change Working Group I Contribution to the IPCC Fifth Assessment Report (AR5). Cambridge University Press, New York, p 25

Trewin D (2004) Year book Australia: 2004. Australian Bureau of Statistics, Australian Government, Canberra Australia

Troedson A, Hashimoto T, Colquhoun G, Ballard J (2015) Coastal Quaternary Geology Data Package for NSW [Digital Dataset]. NSW Department of Industry, Resources and Energy, Maitland

Udale-Clarke H, Ramsbottom D, Dyer B, Wade S, Segura Dominguez S, Bain V, Davison M, Surendran S (2005) Flood risk assessment guidance for new development-Phase 2-Technical report 2. DEFRA, p 374

Wang Y, Chen AS, Fu G, Djordjević S, Zhang C, Savić DA (2018) An integrated framework for highresolution urban flood modelling considering multiple information sources and urban features. Environ Model Softw 107:85-95 
Whetton P, Ekström M, Gerbing C, Grose M, Bhend J, Webb L, Risbey J (2015) Climate change in Australia. Information for Australia's natural resource management regions: technical report, CSIRO and Bureau of Meteorology, Australia. Available at: https://www.climatechangeinaustralia.gov.au/ media/ccia/2.1.6/cms_page_media/168/CCIA_2015_NRM_TechnicalReport_WEB.pdf

Publisher's Note Springer Nature remains neutral with regard to jurisdictional claims in published maps and institutional affiliations. 